\author{
Arnold McMillin \\ Uniwersytet Londyński (Wielka Brytania) \\ University of London (UK) \\ E-mail:a.mcmillin@ucl.ac.uk
}

\title{
The Belarusian Language in the Twenty-First Century as Reflected in the Verse of Young Poets*
}

Stosunek do języka białoruskiego młodych poetów XXI weku

Адносіны маладых паэтаў XXI стагоддзя да беларускай мовы

B efore discussing the ways in which young ${ }^{1}$ Belarusian poets describe the state of their national language, and their development or (sometimes) distortion of it in their verse, it is necessary to outline briefly its history before the twenty-first century.

The road of the Belarusian language has been a thorny one since its heyday in the chancery documents of the Grand Duchy of Lithuania ${ }^{2}$. Since that time it has been discouraged and suppressed by both Poles and Russians, and its literary form or, indeed any printing of it, was banned by the tsarist government until 1905. At that time the problem of using both Roman and Cyrillic alphabets in the early years of „Naša niva” led to uncertainty and diversity rather than unity ${ }^{3}$. After a continuing renaissance in the early years of the Soviet Union, russification soon began apace and, prompted by the Thaw, open dismay found expression, mainly in the work of poets like Janina Janiščyc

* Redakcja „Studiów Białorutenistycznych” zachowała stosowane w Niemczech zasady transkrypcji tekstów białoruskojęzycznych.

1 The poets featured here were all born in or after 1980, thus writing in the period of the present Belarusian regime.

2 The classical description of the chancery language, although published 80 years ago, has retained its validity: C. S. Stang, Die westrussische Kanzleisprache des Großfürstentums Litauen, Dybwad, Oslo 1935.

3 For a good analysis of this problem see: N. Mechkovskaia, Zachem odnomu narodu dve azbuki? (Kirillitsa i latinka v kolliziiach belorusskogo vozrozhdeniia), „Slavia Orientalis”, R. 47, 1998, 2, s. 277-292. 
('Памру за цябе без енку’) $)^{4}$ and Nina Škliarava ('Мова мая! Мой ратунак!') 5 . Нореs of renewed liberalization in the form of glasnost' found rather desperate expression in a letter of 1986 to General Secretary Gorbachev from twenty-eight Belarusian writers, including leading figures such as Vasiĺ Bykaŭ, Ryhor Baradulin, Janka Bryĺ and Aleś Razanaŭ. Their plea, with many necessary references to the wisdom of Lenin and so on, made a powerful case, outlining the vicissitudes of the language in the twentieth century. Here are the second and third paragraphs of this rare document:

Язык - душа народа, наивысшее проявление его культурной самабытности, основа полноценного духовного существования. Пока живет родной язык, живет, имеет историческую перспективу и народ. С упадком языка чахнет, деградирует культура, народ перестает существовать как национальный исторический организм, как бесценная составная часть земной цивилизации.

Язык нашего народа прошел долгий и сложный путь развития. Были у него периоды и упадка и расцвета. Выросший из общих восточнославянских корней, приобретший неповторимые, самобытные черты, он достойно служил нашему народу - имел статус государственного языка в крупной средневековой державе, гордо прозвучал со страниц первой восточнославянской книги, дал миру замечательные образцы белорусской литературы. А в тяжкие годины запрещался и всячески принижался угнетателямі - полонизаторами и русификаторами ${ }^{6}$.

The General Secretary make no reply.

Yet another seriously heavy blow to the language's prospects was the referendum of 1995, which gave equal status to Russian and Belarusian, introduced by the present leader a year after his accession to power?

Young poets of the early twentieth century, by their very use of the language are supporting it and, to some extent, ensuring its continuation. Few of them are sanguine about its neglect in present-day Belarus, but not all express their dismay in memorable form $^{8}$. There are, however some powerful laments over the pitiful state into which the

4 J. Janiščyc, 'I shall die for you without a moan': Mova, U šumie žytnaha śviatla, Miensk: Mastackaja litaratura, 1988, 11.

5 N. Škliarava, 'My language! My salvation!': Maja vioska, Miensk: Knihazbor, 1971, 6. Škliarava subsequently founded a flourishing club for young poets in the Homiel region.

6 'General'nomu Sekretariu Tsentral'nogo Komiteta KPSS tovarishchu Gorbachevu, Mikhailu Sergeevichu', Listy da Harbačova, London 1987, 1.

7 For a good assessment of the situation see Nelly Bekus, ,Hybrid” Linguistic Identity in Post-Soviet Belarus, „Journal on Ethnopolitics and Minority Issues in Europe” 2014, vol. 13, 4, s. 26-51.

8 The same applies to poetic responses to other negative national phenomena. See, for example, the present author's Politics and Criticism in the Work of Young Belarusian Poets, in „East European Review" 2016, VII/1, forthcoming. 
language has fallen. First, however, are two ironic responses to the situation: Maryja Martysievič (b. 1982) in a humorous poem, 'I Maci ich Safija' (And their Mother Sofia), apologizes to the Deity (here described as a beekeeper) for all Belarus's urban obsessions, including feminist blue-stockings' view of all men as goats, and nationalists for giving excessive prominence to the language 9 . Źmitrok Kuźmienka (b. 1980) suggests that although some people may be bored with the subject (an alarming thought for the writer of these lines), it is too important to be simply a matter of fashion:

Нехта мне кіне папрок: „Колькі можна пра мову.

Гэта не модна. Чытач да такога прывык”.TetraSistems,

Быццам бы можа быць модным адчайнае слова,

Вырваны з сэрца ў пустэчу аглухлую крык ${ }^{10}$.

The passionate tone of the last words is typical of this poet. In his 'Ja maŭču...' (I am silent...), for instance, he compares the present state of the language to that of a bird in difficulties

А ў мяне на шматкі

Часам сэрца парвацца гатова:

Так птушка ў бядзе -

Гэта ж родная мова ${ }^{11}$.

In another poem, 'Chto takoje skazaŭ?...' (Who said such a thing?...), Kuźmienka asks a number of challenging rhetorical questions, ending with the language:

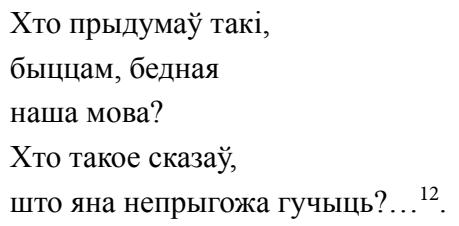

9 Maryja Martysievič, Cmoki liatuć na nierast, Miensk: Lohvinaŭ, 2008 (hereafter Martysievič), s. 103.

10 'Someone will cast a reproach at me, „How much can you write about language. / It is not fashionable. The reader has got bored with such stuff'. / As if a despairing word could be fashionable, / A cry torn from the heart into a deaf wilderness': Źmitrok Kuźmienka, Pakuí žyvu spadziajusia...', Miensk: Halijafy, 2012 (hereafter Kuźmienka), s. 82.

11 'Sometimes my heart is ready to be torn / into pieces; / It is a bird in deep trouble - / That is my native language': Kuźmienka, op. cit., s. 80.

12 'Whoever thought up the idea that our language was poor? / Who said such a thing as that it it sounded ugly?’: Kuźmienka, op. cit., s. 59. 
Aleś Baranoŭski (b. 1989), in a strong poem, 'Rodnaja mova' (My native language) begins with two deeply depressing lines about a desolate land where history is constantly being re-written, but ends with a positive affirmation of the vitality of the language:

Пустазеллем парасла зямля.

Пішуць зноў гісторыю нанова...

$[\ldots]$

Будзе неўміручым тваё слова,

Хай любоў мацнее з году ў год

Да пяшчотных спеваў тваіх мова! ${ }^{13}$

Siarhiej Koŭhan (b. 1984), always a forthright poet, anticipates a brighter future for the language, despite its detractors, in 'Budziem žyć' (We shall live):

Хай крычаць пустасловы варожа,

Што мова нічога не варта.

Слова наша паціху дужае,

Паглядзім, што будзе заўтра ${ }^{14}$.

Hanna Novik in a poem 'Mova' (Language) calls for the native tongue not to be forgotten as long she lives, despite the awful treatment it has received; the first stanza is both appalling and heartening:

Распляжылі. Патрушчылі.

Знявечылі. Забыліся.

Аскепкі неўміручыя

Усё-ткі зліцца сіляцца ${ }^{15}$.

In another poem, 'Imkliva' (Impetuously), after describing the language's pathetic state, Novik specifically sees young people as its salvation when the time comes:

Хай прыйдзе час! Рунь маладая

На ветлівым сонцы заззяе.

13 'The earth is overgrown with weeds. / They are re-writing history again...// [...] // May your word be immortal, / Let love grow stronger from year to year / for your tender melodies, my language': Aleś Baranoŭski, Dyjamientavy nimb dlia aniola, Miensk: Čatyry čverci, 2012, s. 34.

14 'Let hostile windbags shout / That the language is worth nothing. / Our word is gradually growing stronger, / Let us see what there will be tomorrow': Siarhiej Koŭhan, Pieršyja kroki, Miensk: Lohvinaŭ, 2002, s. 6.

15 'They ground down. Smashed. / Crippled. Forgot. / The immortal fragments / are all the same making efforts to come together': Hanna Novik, Sumioty ahniu, Kovčeg, Miensk 2010 (hereafter Novik), s. 31. 
Усё ажыве - вам не дзіва.

...Імкліва ${ }^{16}$.

Śviatlana Kucharevič (d.o.b. unknown) writes in 'Chaj mianie zahajdajuć chvali...' (Let the waves rock me...) of a language that came to her naturally:

Маё цела ахутаюць словы

Зразумелай нявучанай мовы ${ }^{17}$.

Ciemryk Vieliet (b. 1988), notable for his low self-esteem, takes a bleak view of the language's prospects in 'Ja viečna vieru ŭ abrydlaść času...' (I constantly believe in the hatefulness of the times...); the following two lines end on a note of uncertainty:

мой малады ўзрост і адчуванне роднай глебы, і верша, мовы, што сталі ўпоперак усіх але?! ${ }^{18}$

Indifference or deafness to the language is found in Aleś Jemialianaŭ-Šylovič's rather nightmarish poem, 'Čorna-biela-tumannaja kinastužka z hadoŭ tryccatych...' (A misty black and white film clip from the 1930s...), where he imagines himself as a participant in a silent thriller like Nosferatu, while walking around an anonymous Miensk suburb full of anonymous and unresponsive houses: 'Да мовы яны глухія' (They are deaf to the language ${ }^{19}$. Deafness is not quite as bad as enforced memory, of which loss of language is a central part, and Kuźmienka adduces the image of mankurtism in a bitter poem about the subjugation of Belarus and its heritage, including the language: 'Evaliucyja mankurctva, abo Čatyry razmovy z pramiežkami ŭ hady...' (The evolution of mankurtism, or Four conversations with gaps in the years..., Kuźmienka, 76-77). The same reference occurs in an untitled poem by Anatoĺ Ivaščanka, 'Paŭsiudna mankurty...' (Mankurts are everywhere... $)^{20}$.

16 'Let the time come! Young green shoots / Will shine in the welcoming sun. / Everything will come to life - there is nothing to be surprised at. / ...Impetuously': Novik, op. cit., s. 87.

17 'My body is enveloped in words / Of a language that I understand without having studied it': Śviatlana Kucharevič, Ščyra, Miensk: Halijafy 2009, s. 28.

18 'My young age and feeling for the native sod, / and poetry, language that have become contrary to everyone but': Vieliet Ciemryk, Most, Miensk: Wyd. Vielet Ciemryk, 2007, s. 47.

19 Aleś Jemialianaŭ-Šylovič, Parasoniečnaść, Miensk: Kniharnia piśmiennika, 2013 (hereafter Jemialianaŭ-Šylovič), s. 9.

20 Anatoĺ Ivaščanka, VieršNICK, Miensk: Biellitfond, 2006, s. 80.

According to a novel by Soviet Kyrgyz writer Chingiz Aitmatov, Buranny polustanok (I dol'she veka dlitsia den' (Burannyi halt [And a day lasts more than a hundred years], „Novyj mir" $1980,1)$, a mankurt was a man who had been captured into slavery and, after cruel torture, remembers nothing of his previous life. 
After the passionate words and images relating to preservation of the language, among other themes to be discussed in turn are the example of other countries, the use of two orthographic systems, the welcoming or acceptance of trasianka, questions of bad or non-normative language, and attempts at originality through the creation of words and modifications (or complete abandonment) of punctuation and syntactic norms.

The example of the Czechs is inspiring to at least two poets for the way they resurrected their language and used it to strengthen national consciousness and identity. Źmitrok Kuźmienka in ‘Češskim budzicieliam' (To Czech builders) is straightforward in his praise for his fellow-Slavs ${ }^{21}$. Aleś Jemialianaŭ-Šylovič is fulsome in admiration for not only the Czech language but also the people of Prague. In 'Parohi (trypcich miesta)' (Thresholds [triptych of a city]), having started by saying what a pleasure it would be to die in Prague, goes on to lament the fate of poets in his own country:

\footnotetext{
Дружа, хіба не чуў ты пра

Тое, што ў роднай краіне

Паэтам на'ат пасля смерці

Не даюць грамадзянства! ${ }^{22}$
}

The two orthographic systems, taraškievica and the more russified, officially approved, narkomaŭka, both appear in the work of young poets, although this may well be not their own choice, but that of their publishers ${ }^{23}$. Usievalad Ścieburaka (b. 1981) in a ludic poem 'Bielaruskaja kliasyka' (Belarusian classics) opens with a stanza clearly affirming the first system:

Я цьвёрда стаўлю мяккі знак

ва ўсіх належных словах!

Бяз знаку гэтага ніяк

Мая ня можа мова! ${ }^{24}$

It may be, however, that Anka Upala (b. 1981) deliberately uses 'wrong' spelling in her verse as a reaction to the above orthographic differences. In her poem 'Siaredzina' (The middle) she announces that she is a brother of the nineteenth- century

${ }^{21}$ Kuźmienka, op. cit., s. 41.

22 'Friend, have you not heard that / In my native land / Poets even after their death / Are not granted citizenship!': Jemialianaŭ-Šylovič, op. cit., s. 12-13 (12).

23 This phenomenon may be seen very clearly in the works of the historical novelist Uladzimier Arloŭ (b. 1953), whose first name is given by most publishers as Uladzimir, although he himself prefers its more characteristically Belarusian form.

24 'I firmly place a soft sign / in all the appropriate words! / Without this sign no way / Can my language manage': Usievalad Ścieburaka, Bieh pa samaadčuvańni, Miensk: Halijafy, 2013 (hereafter Ścieburaka), s. 25. 
playwright Vincent Dunin-Marcinkievič (1808-1884), observing that neither of them used the Taraškievič system, aware, of course, that not only is there a century between them and the fact that the linguist was born in 1892 , but that, as has already been mentioned, until 1905 it was forbidden to publish works in Belarusian altogether. Upala, unconcerned that Bahdanovič, Pushkin and Mandel'shtam will turn in their graves, advocates the voice of the people:

Ўместа правілаў забытай мовы

Мне майго народа вескі глас 25 .

Such an affirmation leads to the question of trasianka ${ }^{26}$, the mixing of Russian and Belarusian. Although widely regarded as an inferior medium, it is none the less heard widely in Belarus. Anathema to the intelligentsia, it is acclaimed, perhaps ironically, in the already mentioned poem by Ścieburaka, 'Bielaruskaja kliasyka', of which these are the closing lines:

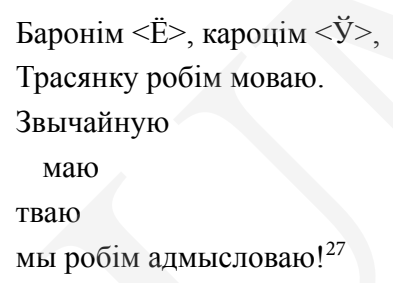

Also worth mentioning is one poet, performer and, allegedly, anarchist of a slightly older generation, Jaryla Pšaničny (pen name of Uladzimir Bańko, b. 1973) who consciously adopts trasianka as the language of his verse ${ }^{28}$.

Several poets use non-normative language. Since most Belarusian swear words are taken from Russian they have relatively little linguistic interest. Maryja Martysievič, who is not herself particularly fond of 'strong' language, has written an interesting essay on the topic, noting ironically that eclecticism is back in fashion: 'Pašli mianie pa bielarusku: Karotki kurs ajčynnaha brydkasloŭja ${ }^{29}$.

A young poet not yet been mentioned is Vital Ryžkoŭ (b. 1986) who had the honour of praise for his debut collection from a respected member of the older generation, Lieanid Halubovič (b. 1950). The latter does, however, suggest that the authors whose

25 'In place of the rules of a forgotten language / For me the voice of my people carries weight': Anka Upala, Dreva Entalipt, Miensk: Lohvinau, 2012, s. 85.

26 Trasianka is the word for a mixture of hay and straw used for cattle feed. In a linguistic sense its nearest English equivalent is probably Creole.

27 'We defend „IO”, shorten „ك̌”, / we make trasianka into a language. / The normal one / of me / and you / we make deliberately!': Ścieburaka, op. cit., s. 25.

28 Jaryla Pšaničny, Piščavyja liški, Miensk: Halijafy, 2011.

29 'Up yours in Belarusian: A short course of our native bad language': Martysievič, op. cit., s. 56-63. 
work Ryžkoŭ translated ${ }^{30}$ had a deleterious effect on his language, particularly in the use of non-normative words ${ }^{31}$.

Finally may be mentioned word-creation, the search for originality through, sometimes pointless, invention ${ }^{32}$. Three poets, like their great predecessor Ryhor Baradulin (1935-2014) provide glossaries and other explanatory notes to their verse collections: The commentaries of Anton Bryl (b. 1982) are purely historical, but Vielet gives 'notes and a little dictionary', whilst Ihar Kulikoŭ (b. 1988) ends his second book, Svamova with extensive notes and 'sloŭje' (words), a considerable glossary of old forms, new creations and other curious words ${ }^{33}$. Kulikoŭ is the most linguistically inventive of the youngest generation of poets, and, indeed, the title of his second book (not in the glossary) defies translation. His first collection contains an untitled poem, 'Halosnych dni padličany. Ich śviet čakaje źhniba...' (The days of vowels are numbered. Decay is awaiting their world...): the bizarre beginning leads to an ending that combines optimism for the future with ambiguity, even self-mockery:

Мы будучыні носьбіты, мы рэзьбіты дарогі,

Варажбіты працьягу, валадары ўсіх сьніб.

Нас будуць прапускаць, не спатыкаючы, парогі,

Апошніх перакладзьбітаў у мову лётніх рыб! $!^{34}$

No less curious are two lines from his poem 'Nieruš' (Nirvana):

Мне сталая мова стуляе дыханьне,

бессловаю товай брыняе у грудзёх ${ }^{35}$.

The title poem 'Svamova' is as challenging as any other of Kulikoŭ's poems, and the last two lines raise as many questions as they answer:

воля да руху вядзе нас празь невымоўны дождж

зноем сваемным таемнай Свамовы ${ }^{36}$.

30 The 'harmful influences' must have been from Wystan Hugh Auden, Ryszard Krynicki, Georgi Nahutsryshvili, Serhij Zhadan, Michael Salinger and Taylor Mali.

31 Lieanid Halubovič, Vakol pieršaj knižki Vitalia Ryžkova. Tezisy da nienapisanaj recenzii, „Dziejasloŭ” 2011, 53, s. 277-282.

32 For the present writer originality has only limited worth in the spheres of art, literature and music - one only has to think of Mozart, far great than Haydn, though not nearly as original. A good example of superfluous 'originality' is the Belarusian translation of Winnie the Pooh as Vinia Pych.

33 Ihar Kulikoŭ, Svamova, Miensk: Lohvinaŭ, 2013 (hereafter Svamova), s. 81-88.

34 'We are the bearers of the future, we are the carvers out of the path, / Foretellers of continuity, lords of all the disabled. / They will let us in at the thresholds without meeting us, / The last translators into the language of flying fish!': Ihar Kulikoŭ, Pavarot na mora, Miensk: Lohvinaŭ,2011, s. 44.

35 'The established language is blocking my breathing, / it is bubbling with wordless energy in my breast': Svamova, s. 13.

36 'the will to movement leads us through inexpressible rain / like our very own heat of the mysterious Svamova': Svamova, s. 27. 
In English, though probably not an inspiration to Kulikoŭ, there is much word creation, at its most oppaque in Finnegans Wake (1922-39) by James Joyce (1882-1941). It is, however, usually used for comic effect, as in Lewis Carroll (1832-1898) or the limericks of Edward Lear (1811-1888). It may be noted that Andrej Chadanovič has produced his own version of the latter genre ${ }^{37}$. Here is a particularly good example of the use of elaborate word creation by an earlier successor of Lear, the American Dixon Lanier Merritt (1879-1972):

A remarkable bird is the pelican,

His beak holds more than his belican. 'Да мовы яны глухія'

He can take in his beak

Enough food for a week -

But I'm damned if I know how the helican ${ }^{38}$.

After the obscurity of Kulikoŭ's Svamova, some of the words addressed to him when he was at school are crystal clear; he recalls them in a prose poem, ' $U$ pierapiskach nasieĺnictva, nia kažučy...' (In the population's correspondence, not to mention...), of which this is the third 'stanza':

Казалі, што ты разумова адсталы і доўга не пражывеш, што сядзеш на голку, ў турму або, не дай божа, паткнесься ў баптыстыя. Але насамрэч цікавіў ты іх не болей, чым нейкі там Банглядэш, Зымбабвэ, родная мова, гомасэксуалістыя ${ }^{39}$.

Despite the heterogeneous and potentially comic combination of things of no interest to the speaker, the quotation above reminds one of the uphill task of many of the most talented and distinguished people in Belarus, as well as the young poets whose very serious thoughts have been discussed. Even a futuristic novel, Mova (The language, $2^{\text {nd }}$ edition 2014) by a relatively young writer, Viktar Marcinovič (born in the Harodnia region in 1977), warns of the danger of the language being lost. It is perhaps natural that young people everywhere should think that it is up to them to change things they do not like, but by writing not only in but also about their native language the new generation of Belarusian poets are the most recent manifestation of a long, necessary and honourable literary tradition.

37 Andrej Chadanovič, Ziemliaki, albo Bielaruskija limeryki, Miensk: Lohvinaŭ, 2005.

38 Dixon Lanier Merritt, 'The Pelican', in Bernard Darwin (comp.), The Oxford Dictionary of Quotations, second edition, reprinted with revisions, London 1970, 337.

39 'They used to say that you were mentally backward, and would not have long to live, that you would take up drugs, land in prison or, heaven forbid, will come across the Baptists. But, in truth, you interested them no more than some Bangladesh or Zimbabwe, the native language, or homosexuals' (p. 25). 


\section{Bibliography}

Aitmatov Czynhiz, Burannyj polustanok (I dol'she veka dlitsia den'), „Novyj mir” 1980, 1.

Baranoŭski Aleś, Dyjamientavy nimb dla aniola, Miensk: Czatyry czwerci, 2012.

Beku Nelly, „Hybrid” Linguistic Identity in Post-Soviet Belarus, „Journal on Ethnopolitics and Minority Issues in Europe" 2014, 13/4, s. 26-51.

Chadanovič Andrej, Ziemliaki, aĺbo Bielaruskija limeryki, Miensk: Lohvinaŭ, 2005.

Ciemryk Vielet, Most, Miensk: Wyd. Vielet Ciemryk, 2007.

Darwin Bernard, The Oxford Dictionary of Quotations, second edition, reprinted with revisions, London: Oxford University Press, 1970, 337.

Halubovič Leanid, Vakol pieršaj knižki Vitalia Ryžkov. Tezisy da nienapisanaj recenzii, „Dziejasloŭ” 2011, 53, s. 277-82.

Ivaščanka Anatol, VieršNICK, Miensk: Biellitfond, 2006.

Janiščyc Jauhienija, Ušumie žytnaha śviatla, Miensk: Mastackaja litaratura, 1988.

Jemialianaŭ-Šylovič Aleś, Parasoniečnaść, Miensk: Kniharnia piśmiennika, 2013.

Koŭhan Siarhiej, Pieršyja kroki, Miensk: Lohvinaŭ, 2002.

Kucharevič Swiatlana, Papou Alieś, Ščyra/Niaščyra, Miensk: Halijafy, 2009.

Kulikoŭ Ihar, Pavarot na mora, Miensk: Lohvinaŭ, 2011.

Kulikoŭ Ihar, Svamova, Miensk: Miedysont, 2013.

Kuźmienka Źmitrok, Pakuĺ žyvu spadziajusia..., Miensk: Halijafy, 2012.

Listy da Harbačova, London 1987.

Martysievič Maryjka, Cmoki latuć na nierast, Miensk: Lohvinaŭ, 2008.

McMillin Arnold, Politics and Criticism in the Work of Young Belarusian Poets, „Przegląd Wschodnioeuropejski” 2016, VII/1.

Mechkovskaia Nina, Zachem odnomu narodu dve azbuki? (Kirillitsa i latinka v kolliziiach belorusskogo vozrozhdeniia), „Slavia Orientalis” 1998, 47/2, s. 277-292.

Novik Hanna, Sumioty ahniu, Miensk: Kaŭczeh, 2010.

Pšaničny Jaryła, Piščavyja liški, Miensk: Halijafy, 2011.

Stang Christian, Die westrussische Kanzleisprache des Großfürstentums Litauen, Oslo: Dybwad, 1935.

Ścieburaka Usievalad, Bieh pa samaadčuvańni, Miensk: Halijafy, 2013.

Šklarava Nina, Maja vioska, Miensk: Knihazbor, 2012.

Upala Anka, Dreva Entalipt, Miensk: Lohvinaŭ, 2012. 
The Belarusian Language in the Twenty-First Century as Reflected in the Verse...

\section{Streszczenie}

W artykule autor omawia kondycję języka białoruskiego w XX i XXI wieku oraz stosunek współczesnych młodych poetów do języka ojczystego, odzwierciedlony w ich twórczości poetyckiej. Przytoczono zarówno przykłady obojętności młodych poetów białoruskich wobec języka ojczystego, jak i zatroskania o jego los.

Słowa kluczowe: język białoruski, historia, zachowanie języka, warianty, wzorce, akceptacja, lekceważenie

\section{Резюме}

В этой статье дается краткая история положения белорусского языка в XX-м и XXI-м веках, и, в частности, разные случаи упоминания о нем в стихах молодых поэтов; анализируются художественные образы, с помощью которых описывается отношение к белорусскому языку в их творчестве. Приводятся примеры как равнодушия к судьбе родного языка со стороны молодых поэтов, так и его страстной защиты.

Ключевые слова: белорусский язык, история, сохранение, варианты, образы, похвала, пренебрежение

\section{Summary}

This article traces briefly the history of the Belarusian language in the $20^{\text {th }}$ and $21^{\text {st }}$ centuries, particularly the ways in which it is used by young poets, and the imagery used to describe it in their works. Also shown are some of the ways the language is spurned and passionately defended.

Keywords: Belarusian language, history, preservation, variants, imagery, praise, scorn 